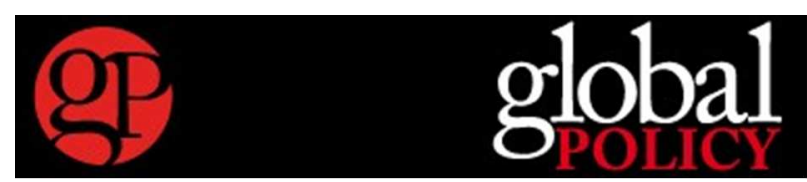

\title{
Governance as a Global Development Goal? Setting, Measuring and Monitoring the Post 2015 Development Agenda
}

\begin{tabular}{|c|c|}
\hline Journal: & Global Policy \\
\hline Manuscript ID: & GPOL-Mar-2014-RA-0173.R2 \\
\hline Wiley - Manuscript type: & Research Article \\
\hline Keywords: & $\begin{array}{l}\text { Governance, Institutions, Development goals, Measurement , Post } 2015 \\
\text { development agenda }\end{array}$ \\
\hline Abstract: & $\begin{array}{l}\text { The increasing realisation that governance quality is a fundamental } \\
\text { element of long-run development has led to its consideration as a desirable } \\
\text { development goal in its own right. To contribute to such a process, this } \\
\text { paper provides a framework to set, measure and monitor governance goals } \\
\text { in the Post } 2015 \text { Development Agenda. First, we assess whether existing } \\
\text { cross-national measures on governance quality can be exploited to } \\
\text { measure and monitor aspects of legal, bureaucratic and administrative } \\
\text { quality. Such a "quick fix" approach to measuring governance quality is } \\
\text { fraught with challenges. The current practice of measurement is still } \\
\text { subject to the short country coverage of most available measures, issues of } \\
\text { comparability and legitimacy, as well as methodological shortcomings. } \\
\text { Second, we argue that, in the long run, measuring and monitoring } \\
\text { governance quality may require reconceptualising "good governance" and } \\
\text { designing internationally shared measures that are routinely provided by } \\
\text { national statistical offices, (but, international groups should also continue } \\
\text { to make their independent measures). Finally, we consider the different } \\
\text { approaches to setting governance goals, arguing in favour of a combination } \\
\text { of national target setting and minimum standard with continuous } \\
\text { improvement. }\end{array}$ \\
\hline
\end{tabular}




\title{
Governance as a Global Development Goal? Setting, Measuring and Monitoring the Post 2015 Development Agenda
}

\begin{abstract}
The increasing realisation that governance quality is a fundamental element of long-run development has led to its consideration as a desirable development goal in its own right. To contribute to such a process, this paper provides a framework to set, measure and monitor governance goals in the Post 2015 Development Agenda. First, we assess whether existing cross-national measures on governance quality can be exploited to measure and monitor aspects of legal, bureaucratic and administrative quality. Such a "quick fix" approach to measuring governance quality is fraught with challenges. The current practice of measurement is still subject to the short country coverage of most available measures, issues of comparability and legitimacy, as well as methodological shortcomings. Second, we argue that, in the long run, measuring and monitoring governance quality may require reconceptualising "good governance" and designing internationally shared measures that are routinely provided by national statistical offices, (but, international groups should also continue to make their independent measures). Finally, we consider the different approaches to setting governance goals, arguing in favour of a combination of national target setting and minimum standard with continuous improvement.
\end{abstract}

Key-words: governance, institutions, development goals, measurement, post-2015 development agenda. 
Most scholars and policy makers would agree that the design of rules and regulations, the effectiveness of policies and the competence of public bodies play a crucial role in the functioning of economies. In short, governance matters. Since the early 1990s, an increasing amount of research focused on the quality of governance as a determinant of national income levels and economic growth rates. Although its effects on other important development outcomes - such as inequality, health and education - have received less attention, the current consensus is that "good governance", or perhaps more accurately "good enough governance" (Grindle 2004), is a prerequisite for development (e.g., Baland, Moene and Robinson 2010, Cingolani et al. 2013).

The findings of this research have led to increasing recognition of the importance of its role to the point of considering governance a desirable global development goal in its own right (see United Nations 2013 and section 2). This paper seeks to contribute to this process by exploring the possibility of setting and monitoring governance goals for the Post-2015 Development Agenda. In order to do so, one must necessarily look also at the possibility of routinely measuring governance goals. Hence, our task requires assessing how, and how well, existing databases and measures capture governance quality: which aspects they measure; what and how robust their methodologies are. We examine the trends for measures of legal, bureaucratic and administrative quality, assessing to what extent such measures can be used, in terms of both political acceptability and statistical desirability.

We will argue that the idea of "good governance", as often captured, can be a highly controversial one (for example see Sundaram and Chowdhury 2012) and risks neglecting the centrality of context to effective institutional reform (Andrews 2013). Hence, existing measures, while offering a quick solution for the Post-2015 Development Agenda, may not reflect a "politically shared" notion of governance quality. We also argue that we need to think long term: how to develop a professional cadre, setting international standards and 
getting national statistical offices engaged, so that governance measures become part of a routinised, national statistics activity producing internationally comparable data. This is long term, but it is what the UN has specialised in, and had a lot of success, since 1950 (Ward 2004). It would ensure that the Post-2030 Development Agenda has well thought out and high quality governance measures.

The paper proceeds as follows. Section 2 provides a background discussion on the approaches and controversies of governance quality measurement. Section 3 examines the potential of available indicators to capture governance goals, presenting some statistics. Sections 4 and 5 discuss the possibility of monitoring and setting governance goals in the Post 2015 Development Agenda. Section 6 concludes.

\section{Measuring governance as a development goal}

This section provides the background discussion on existing approaches and controversies on measurement and their implications for governance as a development goal. This requires two building blocks. Firstly, we need to define the object of measurement and its dimensions. Secondly, we must discuss the methodological issues and the properties of governance measures.

\subsection{Defining what to measure}

The concept of governance is commonly viewed as elusive or as ambiguous. According to the Oxford English Dictionary, governance is "The manner in which something is governed or regulated; method of management, system of regulations". Detailed discussions of its conceptual underpinnings often conclude there is no widely accepted definition that can be operationalised (e.g., Bevir 2011 and Holmberg et al 2009). The World Bank's definition of governance as "the manner in which power is exercised in the management of a country's 
economic and social resources for development" (World Bank 1992, 1) is used extensively in the literature. In practice, the analysis of governance has fitted a multiplicity of dimensions: from the type and quality of political institutions to the set of economic institutions and policies. In particular, political democracy is often considered as part of (good) governance. In democracies, citizens and parties enjoy substantial representation and executive power is subject to checks and balances. Such characteristics may often be associated with the attainment of economic and human development goals. However, this paper is not concerned with aspects of democracy or political regimes, for two reasons. First, the role of democracy is still controversial as, historically, developmental states in Asia existed under authoritarian regimes (e.g., Taiwan and South Korea). Indeed, even authoritarian regimes differ so greatly that thinking that such a category has analytical utility may be far-fetched. Whether and how political regimes affect the quality of governance remains an open question (e.g., Mulligan et al. 2004; Bardhan 1999). Second, the analysis of political democracy and political regimes relate to aspects of access to power. It seems conceptually appropriate to keep the issue of access to power separate from the one on the exercise of power (Mazzuca 2010) ${ }^{\mathrm{i}}$ As Fukuyama (2013) argues, "governance is about the performance of agents in carrying out the wishes of principals, and not about the goals that principals set" (p. 350).

Hence, this paper adopts a definition of governance that separates the quality of governance from the nature of the political regime in the country in question. Under this definition, governance is the effectiveness of rules, policies and the functioning of public bodies that affect the lives of the members of a community. Even from such a narrower starting point that focuses on the organisation of the state and how effectively it executes policies and programmes, identifying the objects of measurement is not straightforward. Theories of development disagree on which and how many dimensions of governance are crucial to prosperity. The type of governance that promotes it may vary according to the proposed 
mechanisms through which institutions and policies affects development outcomes: some emphasise the protection of property rights (see Acemoglu and Robinson, 2012; and Tabellini 2005); others point to the role of the state involvement in overcoming coordination failures (e.g., Bardhan 2005); or of protecting specific economic sectors, supporting technological innovation, providing infrastructure and engaging in human capital formation (e.g., Evans 1995). Consequently, the concept of governance must be mapped according to the functions one deems key to development.

Based on the existing economics and political science literature, one can differentiate between three conceptually separate dimensions of governance (as being understood as the capacity of the state to implement rules and policies effectively), that are seen as being crucial for the achievement of inclusive development. These are:

- Bureaucratic and administrative systems. Whatever we may maintain a state should do to foster development, it needs a bureaucratic apparatus to design and implement policies. This dimension is central to all areas of research on the state and development. Traditionally, state capacity indicators focus on the competence and ability of bureaucracy (e.g., Evans and Rauch 1999 Rauch and Evans 2000), and generally include the ability of raising tax and spending the proceeds efficiently on important public goods (Ottervik 2013).

- Legal infrastructure: the capability of a legal framework of enforcing contracts and property rights (i.e., a judicial system for settling disputes, rule of law). The consensus is that, at the very least, the state has to provide such public goods, as they are ill-suited to private provision (Besley and Persson 2011; Lin and Nugent 1995).

- Transparency and Accountability: While there may be disagreement on the appropriate nature of the state in fostering economic development, there seems to be increasing 
realisation on the importance of transparency and accountability in shaping the legitimacy of state institutions and the quality of governance. Here, transparency and accountability is broadly understood to be about the relationship between the citizen and the state and the extent to which the state is answerable for its own actions and inactions (UNDP 2011). Transparency and accountability are seen as important elements of the effectiveness of states in delivering essential services such as education, health and infrastructure effectively to the poor (World Bank 2004, Rakjumar and Swaroop (2008)).

The transparency and accountability component of the 'good governance' agenda has been mostly clearly reflected in the Post-2015 Development Goal on Governance in the High-Level Panel (HLP) Report (United Nations 2013). As Table 1 illustrates, all five dimensions of Goal 10: Ensuring Good Governance and Effective Institutions, as formulated in the HLP report, address transparency and accountability, in some degree. It is noteworthy that bureaucratic capacity and legal infrastructure do not seem to figure so clearly in the post-2015 MDG goal on Governance, when there is a large body of evidence that these dimensions of governance matter more for inclusive development (Evans and Rauch 1999; Besley and Persson 2011; Savoia and Sen 2014).

[Table 1 about here]

\subsection{Methodological issues}

Empirical research on governance quality has designed numerous and diverse measures: on the protection of property rights; quality and performance of the bureaucracy; the administration of justice; and micro and macroeconomic management. ${ }^{\text {ii }}$ This section reviews the methods and findings from such literature. 
A popular classification divides governance indicators between objective and subjective measures (e.g., see Williams and Siddiqui 2008). Examples of measures constructed from "hard" data often come from the state capacity literature. Proxies can draw on economic variables, such as tax effort (e.g., Hendrix 2010; Hanson and Sigman 2013), military expenditure (e.g., Hanson and Sigman 2013) or even national income measures (Fearon and Laitin 2003). Others drew on infrastructure and public sector variables, such as railroad or road density and census administration (Centeno 2002; Hanson and Sigman 2013) or military personnel (Hendrix 2010). A second class of objective measures is rule-based, i.e., constructed by rating the existence and strength of certain formal (de jure) rules. Examples of rule-based measures of governance are those compiled by Global Integrity such as whether a country has regulations requiring an impartial, independent and fairly managed civil service (administrative capacity), laws that require competitive bidding of major government procurement contracts (legal infrastructure) and in law, citizens can access the asset disclosure records of members of the national legislature (Global Integrity Report 2011).

Alternatively, subjective measures are perception-based, i.e., ratings rely on perceptions of the de facto functioning of rules, coming from: (i) experts' opinions, e.g., risk-rating agencies, foreign investors, academics or NGOs; and (ii) surveys of national respondents (firms or individual citizens). Surveys have the advantage of capturing the views of domestic agents directly involved in the institutions of the country, but are more expensive to administer and less suitable for cross-country comparability than expert assessments (Williams and Siddiqui 2008).

Which types of measures have the most desirable properties? Methodologically, proxies from hard data are free from the political or ideological bias that experts' assessments may have. Perhaps the main limitation of such proxies is that they may be outcomes of governance, rather than an assessment of its quality (and may change as a result of changes in factors 
other than reforms in the governance apparatus, e.g., such proxies may reflect the role of national culture and values). Similarly, the advantage of rule-based indicators is that they are not affected by observer's bias. In addition, such measures have the advantage of synthesising many and diverse formal institutional and policy elements into a single aggregate governance index. However, they could well be vulnerable to gaps between the essence of rules and codes and how they function on the ground (e.g., bribes can be codified as illegal, but no agency actually enforces this law). Therefore, rule-based measures may exhibit "systemic isomorphic mimicry" - where countries adopt the outward forms (such as appearances and structures) of functional states and organisations elsewhere to camouflage a persistent lack of function (Pritchett et al. 2013). Thus, while Ghana, Uganda, India and Venezuela receive the same score from the Global Integrity Report 2011 in terms of the existence of procedures on the meritocratic recruitment and promotion of civil servants, the same report finds that in practice, civil servants in Ghana and Uganda are twice as likely to be appointed and evaluated according to professional criteria, when compared to India and Venezuela. This suggests that de facto measures, which are be sensitive to any institutional and policy change: both formal and informal, may be preferred to rule-based or de jure measures of governance.

Apart from being prone to observer's bias, an additional limitation of subjective indicators is that they cannot indicate which specific policy intervention is actually responsible for observed changes in governance quality. ${ }^{\mathrm{ii}}$ There is no compelling reason to believe that, for instance, a policy intervention aimed at improving the rule of law affects other aspects of the institutional environment, such as the recruitment of bureaucrats. This may or may not happen, depending on the actual policy and the degree to which this is implemented. Yet, the correlations amongst popular perception-based measures show that different dimensions of governance are significantly and positively correlated among themselves (see Hulme et al 
2014), suggesting that policy interventions in one area might be perceived as improving the general governance environment. Hence, perception-based indices might have limited power in distinguishing different attributes of governance. However, such regularities could alternatively suggest that there are significant complementarities amongst dimensions of governance (as argued in Besley and Persson 2011), in which case subjective measures would correctly record a simultaneous change in all the components.

Despite these potential limitations, there is scope for using subjective assessments: having a wider range of measures increases the number of dimensions that policy makers can monitor. But one must carefully choose the appropriate measure or combination of measures, if the issue of governance under scrutiny demands. To this aim, Table 2 summarises types and properties of governance measures. Moreover, even when they purportedly capture similar aspects, governance measures should not be necessarily considered interchangeable. As the concept of governance quality remains ambiguous, similar measures may express distinct aspects of governance.

[Table 2 about here]

Having provided an overview of the methodological issues, we finish the section with some remarks on the construction of a composite index, which would aggregate the dimensions of interest. A synthetic index, while not always desirable for academic research, would be quite useful to policy makers. But this begs the question of how many dimensions should be part of a composite index. Even if one could reach a consensus on which governance dimensions should be included, we would still be left with the task of elaborating an appropriate formula to combine the would-be components. For example, should it be additive or multiplicative? This can only be decided on the basis of further theoretical foundations on what constitutes governance for development. ${ }^{\text {iii }}$ Meanwhile, policy makers wishing to draw on existing data 
may wish to use disaggregated measures, although it can be argued that using such "dashboards" may encourage idiosyncratic choices and weaken the accumulation of knowledge about governance and its effects. From this, it follows that a useful property of any aggregate governance index is to make its components available. On the other hand, if one believes that there could be complementarities among different elements of governance, further discussion on a composite measure combining different aspects would have greater scope.

\section{Governance indicators for the Post 2015 Development Agenda}

What are the available measures that could be potentially used for the Post 2015 Development Agenda? Measuring governance quality has gradually become an industry that sees NGOs, research organisations and commercial providers operating in this field. Reviews and guides on governance measurement (e.g., Teorell et al 2013, Foresti et al. 2014), provide a broader overview of the available databases and measures. This section assesses a selection of representative indicators on the areas of governance identified above (but the list could be longer, such is the size of the governance rating industry). To see how governance quality has evolved, we also illustrate their trends over time.

Table 3 gives a snapshot comparison of selected governance indicators on the three dimensions of governance discussed earlier - administrative capacity, legal capacity and transparency and accountability. Three facts stand out: (i) the current practice of measuring governance quality seems to privilege methodologies based on a subjective approach; (ii) policy makers interested in the areas of legal capacity, transparency and accountability and bureaucratic and administrative quality can choose from a variety of indicators; (iii) efforts to provide comparable governance measures often face the constraint of limited country coverage.

[Table 3 about here] 
To give an illustration of the temporal evolution, we examine two databases that, measuring legal and administrative quality, allow observing governance over the longest period: the Quality of Government ( $Q o G)$ index assembled by Teorell et al. (2013) and the Quality of Legal Structure and Security of Property Rights index (QoLSSPR) (Gwartney et al 2013). In both cases, the ratings come from subjective assessments of foreign investors and business experts. $^{\text {iv }}$

The $Q o G$ is calculated as the average of rule of law, corruption in government, and bureaucratic quality indices from various editions of the International Country Risk Guide (ICRG 2012). It spans from 1984 to 2010 and is rescaled to lie between 0 and 10 . This index seems to capture some of the dimensions of governance quality that are implicit in the Governance Goal in the HLP report, particularly in its rule of law and anti-corruption dimensions. However, the fact that it is expressing the views of the business community does raise concerns over its representativeness and legitimacy.

The QoLSSPR is, instead, a proxy for legal capacity. A component of the Fraser Institute Index of Economic Freedom, such variable is continuous and ranges between 0 and 10, with a higher score corresponding to higher quality (see Gwartney et al 2013). It has been recorded every five years from 1970 until 2000 (and every year from 2001 on). Unfortunately, it samples fewer countries than the ICRG database and it has been assembled over the years from different sources. Like the $Q o G$, also the $Q o L S S P R$ is constructed from commercial ratings produced by the business community (including the ICRG, the Business Environment Risk Intelligence and the Global Competitiveness Report), raising the same concerns over its representativeness and legitimacy.

Table 4 shows the trends in advanced, developing and transition economies over 2000-2010. The first stylised fact is the gap in governance quality between advanced economies and the 
rest remains wide and stable. A second stylised fact is that both measures show that advanced economies remain a more homogenous group than developing and transition economies.

\section{[Table 4 about here]}

Governance quality appears to be a slow-changing phenomenon and it should also be analysed over a longer period. Figure 1 below provides further details of the $Q o G$ and QoLSSPR by disaggregating the developing countries group by region. The end of the Cold War was accompanied by sharp improvements in governance quality, suggesting that it has been a positive shock. ${ }^{v}$ QoG shows a spike for all groups of countries in the mid 1990s, where all regions of the developing world seem to move closer to the advanced economies. But the subsequent worsening slows this process, although some convergence seems to have occurred. The QoLSSPR presents a similar evolution across regions. The group of countries that has improved governance quality most compared to its initial level is the MENA region (followed by Latin America), in terms of the QoLSSPR, and Asia (followed by Latin America), in terms of the $Q o G$. Note also that in both cases the transition economies have experienced a significant decrease in governance quality after the end of the Cold War.

\section{[Figure 1 about here]}

Apart from providing some stylised facts, the evidence in this section illustrates the difficulties faced by policy makers wishing to monitor governance for the Post 2015 Development Agenda. Figure 1 reveals that changes in the quality of governance and legal structure and property rights are relatively slow. Changes in governance quality originate from institutional changes. These are long-run phenomena that are best monitored with relatively low frequency data. Attempts to measure such variables on an annual basis may be as likely to change because of measurement error as much as substantive change. This 
suggests that monitoring of such indicators might be best framed as every five years (and not annually) or as a three year rolling average.

Finally, if 2005 is selected as the 'start' of the monitoring period for achieving post-2015 goals (as was the case with the MDGs with a 1990 'start' for goals set in 2000), then the only available database that can provide measures for all the UN's 193 member countries, and for three governance dimensions identified here, is the World Governance Indicators (World Bank 2011). However, amongst the limitations of such database, one would still have to address concerns of comparability over time (see Arndt and Oman 2006), as the secondary datasets they draw from have changed over time. Data from commercial organisations is only available on approximately 140 of the UN's 193 member countries. Moreover, the possibility of reconstructing the data for missing countries is quite limited, if not impossible, for measures adopting a subjective approach.

\section{Monitoring governance: which way? Options and choices}

This section first reflects on the challenges facing measuring and monitoring governance: finding a "politically acceptable" dimension(s) of governance, which is consistent across countries and over time. The second task of this section is to set the scene for the long term, i.e., developing the capabilities for comparative and routinised production of governance measure in UN member countries.

\subsection{Thinking short term}

The Post 2015 Development Agenda, following the results-based management principles that underlay the MDGs, seeks to have 'SMART' goals and targets - specific, measurable, attainable (but stretching), relevant and time-bound (Hulme 2010). For the contemporary timetable (i.e., 2015), which requires a baseline without having the time to develop new 


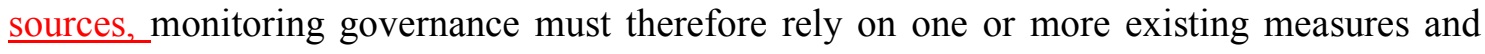
databases. Apart from the methodological and data quality problems discussed earlier, this approach presents a number of further challenges.

Firstly, most governance databases do not include a significant number of developing countries. Apart from the WGIs, a significant number of available governance measures, especially those produced by political risk consultancies for a clientele of foreign investors (e.g., the ICRG), are not comprehensive. Apart from coverage problems, using commercial organisations data may also raise issues of legitimacy, as they reflect solely the views of the business community.

Second, as Kauffmann and Kraay (2008) have stressed, governance measures can be subject to measurement error as the "true" concept of governance one would like to measure is difficult to define. Therefore assessing specific governance aspects in different countries could face problems of comparability across countries and over time. Even the most trusted measures are not immune to this. However, future empirical analysis could explicitly examine this problem, so shedding further light on the degree to which measurement error and conceptualisation may shape changes in a measure. ${ }^{\mathrm{vi}}$

Third, one should reflect on which governance dimensions and measures should be included. There are two ways to approach this issue. One could argue that good governance has an intrinsic value in itself, similar to Goal 2 in the post-2015 goals proposed by the HLP, which is on the empowerment of girls and women. Such an approach takes the Universal Declaration of Human Rights as the basis for good governance, which as the HLP report notes, 'sets out the fundamental freedoms and human rights that form the foundations of human development' (United Nations 2013, 30). Or one could argue that good governance has instrumental value, and that improvement in governance quality has tangible effects on 
both material and non-material dimensions of economic development. For the former, measures of governance that capture the nature of state-society relations, or of the degree of state legitimacy and accountability, would take precedence in the development of indicators for the post-2015 goals. For the latter, a good starting point is to base such a choice on the empirical literature using governance measures to estimate their effects on development outcomes. Findings from econometric analyses at cross-country level in this area are mainly aimed at explaining economic growth and national income levels, focusing on the contracting and legal environment, suggest that protection of private property rights is positively and robustly associated with national income levels. However, even if most would agree that property rights institutions are crucial to get incentives right, protecting private property rights represents a political challenge. This literature is not clear on whose property rights one should protect (e.g., peasants or landlords, capitalists or workers, foreign or domestic investors, etc.). ${ }^{\mathrm{vii}}$ Moreover, other important development outcomes, such as inequality, health, education and poverty, have received scant attention so far within this line of research.

Further recent research highlighting the instrumental value of governance, building on the well-established literature on developmental states (e.g., Evans 1995; Evans and Rauch 1999; and the collection of articles in Lange and Rueschemeyer 2005), increasingly recognises the importance of state capacity as a fundamental ingredient for economic development. Approaching governance from this angle would suggest that the focus in the post-2015 goals should be on indicators that capture the administrative and legal capabilities of states. However, this still poses a significant measurement challenge, as there is no universally accepted measure of state administrative and legal capabilities. Existing measures such as the WGIs, the ICRG measure of bureaucratic quality or the Evans-Rauch measure (which captures the Weberian properties of the bureaucracy) have both strengths and weaknesses. The WGIs are non-comparable over time as recalled in the previous section (as well as not 
being very clear whose opinions they represent). The ICRG and the Evans-Rauch measures are perception based and depend on the opinions of a limited set of experts. As Fukuyama (2013) has argued, the Evans-Rauch measure is the closest to what we understand by state capacity - "the government's ability to make and enforce rules, and to deliver services" (Fukuyama 2013, 387). Under this definition, governance is about "the performance of agents in carrying out the wishes of principals, and not about the goals that principals set" (ibid.). While the Evans-Rauch measure may be the most desirable from a theoretical standpoint (if we agree with Fukuyama's definition), it is handicapped by the lack of time-series data, and the very limited coverage of countries (30 countries). One important issue here for further discussion is that if indeed we were to base a measure of governance on the Evans-Rauch approach, how would we go about conducting the expert surveys which form the basis of the measure, and how can we make sure that most, if not all, developing countries are covered by this measure?

\subsection{Thinking long term: towards 2030}

The idea of setting governance goals for the Post 2015 Development Agenda, and subsequently monitoring them has important implications for the long-term development of comparative governance measures that are recognised as authoritative by all (or at least the vast majority) of UN member states. Including governance goals in the Post 2015 Development Agenda has potential advantages for the evolution and institutionalisation of governance statistics: but, it also has dangers.

On the positive side, the inclusion of governance goals (or targets or indicators) would increase the pressure on governments, bureaucracies, professionals/researchers and civil society to collect relevant data and improve the quality of such data. Arguably, the greater availability of such data would lead to a greater focus on improving governance. 
On the negative side, the rapid selection of a measure(s) to meet the 2015 deadline might:

- Lead to the selection of a sub-optimal measure from 'what is available'. This would mean that the interpretation of changes in governance in the future would be challenged both technically (the measure is flawed) and politically (the measure is ideologically biased against some countries).

- Damage the long-term evolution of a professional cadre of 'governance statisticians'; of widely accepted standards and measures for governance; and, the institutionalisation of governance measures as a routine part of national and international data collection and analysis.

In an ideal world, those engaged in setting the Post 2015 Development Agenda would carefully assess the trade-offs of focusing on the short term task of identifying measures for 2015 against the long term task of institutionalising top quality governance statistics across the world. In the world we live in, leaders in this field may need to focus on developing 'the best measures we can for $2015^{\prime}$ while setting in motion processes that will promote the institutionalisation of governance statistics longer term. One 'governance target' would be that by 2020 all UN member states could produce a basic set of governance statistics that meet an international standard ${ }^{\text {viii }}$. One of the great successes of the UN system - but a 'quiet success' - has been its contribution to the evolution of globally accepted statistical measures, quality standards, statistical professionals and national statistical capacities (Ward 2004). The quality of these national measures could be partly assessed by independent analysts comparing what national statistical measures with the independent measures produced by international groups. 


\section{Approaches to Setting Governance Goals}

Finally, mention must be made about the different ways in which governance goals/targets/indicators could be set and the relative strengths and weaknesses of these approaches. The MDGs used a number of different types of target ${ }^{\mathrm{ix}}$.

(i) Percentage reductions/improvements in outcomes - Most common were percentage reductions in bad outcomes (e.g., halving income poverty, reducing child mortality by two-thirds) partially based on stretching (i.e., accelerating) the pre-existing rate of improvement in such indicators. For governance measures, for which there is such limited data on historical rates of change, this approach has limited relevance.

(ii) Universal outcome achievement - Also common was the universal achievement of some targets by 2015 (e.g., universal primary education, elimination of gender disparities in education, full employment, universal access to reproductive health). For governance measures, conceptualising universal achievements is highly problematic: what would 'universal accountability' or 'total transparency' or 'full property rights' actually mean?

(iii) Absolute outcome achievement - Less common, and rather strange because of its arbitrariness, was the setting of absolute global targets (e.g., significantly improving the lives of 100 million slum dwellers). Given the existing dissatisfaction with these MDG measures, there seems to be little point in pursuing such an approach, as the justification of such targets would have no (or very limited) technical basis.

(iv) Process-based targets - There were also a number of 'process-based' targets for issues that were hard to quantify and/or were politically controversial. These did 
not set outcome targets but called for improved national and/or global processes (e.g., the integration of sustainable development principles into national policies, the development of a fairer global trading and financial system, action to address the needs of the least developed countries). Such an approach might be possible for some governance targets but, learning from the MDG experience, actual targets and completion dates would need to be specified if they are to encourage countries (or the international community) to accelerate progress in improving important processes.

For governance targets, one could also identify at least two other approaches to setting targets.

(v) Minimum standard with continuous improvement - that a universal minimum standard be achieved by a set date but that all countries should be continuously improving on their achievement (so that all countries achieve the minimum target but no country can 'relax' simply because that minimum standard has been achieved). As an example, by 2030 all countries achieve a target of 80 per cent of social transfer recipients reporting 'no corruption' when accessing transfers and, for all countries that have achieved this target, continued reductions in reports of corruption on an annual basis.

(vi) National target-setting - that all countries agree to a goal but that some form of inclusive, national decision-making process sets the actual target (so that targets are not 'imposed from above'). For example, a UN target that all countries are to reduce recipient reported levels of social transfer corruption on an annual basis but the specific rate of reduction ( 5 per cent or 10 per cent per annum) is to be determined independently by each national legislature based on a national debate on what is desirable and feasible in that specific context. 
Careful consideration will need to be given to the issue of what approaches to goals and target setting are best for governance. Given that many governance goals and targets are about improving processes, approaches (iv), (v) and (vi) are the logical preference. In particular, combinations of approaches (v) and (vi) are particularly attractive as they could permit the setting of global minimum targets at the UN integrated with democratically set national targets. National targets would set either 'faster' achievement of the UN global targets or set the rate at which higher levels of target achievement are to be attained). However, given the MDG Goal 8 experience, such approaches would have to avoid weak specification that permits them to be side-lined by member states.

\section{Conclusions}

This paper has offered an overview of the strengths and limitations in current empirical research on governance quality and their implications for measuring, setting and monitoring governance goals and targets in the Post 2015 Development Agenda. Of particular significance are ongoing debates about whether good governance is good for development and/or, whether good enough governance is the best to which nations can aspire.

It will be important for those engaged in improving governance to think both short term and long term about setting, measuring and monitoring governance goals/targets. We have argued that, in the short term, existing measures on governance quality used in cross-national research can be exploited by policy makers shaping the Post 2015 Development Agenda to capture aspects of legal, bureaucratic and administrative capacity. We have utilised them to provide stylised facts on its evolution. However, such an approach is subject to a number of challenges, e.g., country coverage, data comparability and the ideological base of the concepts of governance measured. As a consequence, setting and monitoring governance goals should be seen as planning for the long run. Longer term, policy-makers need to think 
about how the selection of goals/targets for the Post 2015 Agenda can go beyond rapidly creating Goal 10 of the HLP's Illustrative Goals and foster the institutionalisation (measures, methods, standards, training, professional accreditation) of high quality governance statistics at both national and international levels. The Post 2015 Development Agenda is only one early step along the path to establishing measures of governance as a routine statistical artefact, as has happened with the economic and social statistics that we take for granted today.

\section{References}

Acemoglu, Daron and James Robinson (2012) Why Nations Fail: The Origins of Power, Prosperity and Poverty. London: Profile Books.

African Union (nd) Strategies for the Harmonisation of Statistics in Africa, Addis Ababa, AU.

Andrews, M. (2013) The Limits of Institutional Reform in Development. Cambridge: Cambridge University Press.

Arndt, C. and C. Oman (2006), Uses and Abuses of Governance Indicators, OECD Development Centre Studies, Paris.

Baland J.-M., Moene K.O., Robinson J.A. (2010) “ Governance and Development”, Chapter 69 in the Handbook of Development Economics, Volume 5, 2010, Pages 4597-4656, Elsevier.

Bardhan, P. (2005) Institutions Matter, but which ones?, Economics of Transition 13(3): 499532.

Bardhan, P., (1999). 'Democracy and Development: a Complex Relationship', in Shapiro, I. and Hacker, C. (eds.), Democracy's Values, Cambridge University Press.

Bertelsmann Foundation (2011) Bertelsmann Transformation Index. Available at: http://www.bertelsmann-transformation-index.de/en/bti/ .

Besley, T. and Persson, T. (2011) Pillars of Prosperity: The Political Economics of Development Clusters, Princeton University Press.

Bevir M., ed., (2011) The Sage Handbook of Governance, London: Sage.

Centeno, M. A. (2002). Blood and Debt: War and the Nation-State in Latin America. Penn State Press.

Chang H-J., (2011), Institutions and economic development: theory, policy and history, Journal of Institutional Economics, 7: 4, 473-498. 
Cingolani, L., K. Thomsson and D. de Crombrugghe (2013), "Minding Weber More Than Ever? The Impacts of State Capacity and Bureaucratic Autonomy On Development Goals", UNU-MERIT Working Paper No. 52

Evans P. (1995) Embedded autonomy: states and industrial transformation. Princeton: Princeton University Press.

Evans P.B. and Rauch J.E. (1999) Bureaucracy and growth: a cross-national analysis of the effects of 'Weberian' state structures on economic growth. American Sociological Review, 64(5): 748-765.

Fearon, J. D. and Laitin, D. D. (2003). Ethnicity, insurgency, and civil war. American Political Science Review, 97(1):75-90.

Foresti, M., L. Wild, L.R. Takeuchi and A. Norton (2014), Governance Targets and Indicators for Post 2015: An Initial Assessment, Overseas Development Institute: London, Working Paper.

Fukuyama, F. (2013), What is Governance?, Governance, Vol. 26, No. 3, pages 347-368.

Goertz, G. (2006), Social Science Concepts: An User's Guide, Princeton: Princeton University Press.

Global Integrity, Global Integrity Report 2011, available at: https://www.globalintegrity.org/downloads/

Grindle, M. S. (2004), Good Enough Governance: Poverty Reduction and Reform in Developing Countries. Governance, 17: 525-548.

Gwartney, J.G., Robert Lawson, and Joshua Hall, Economic Freedom of the World: 2013 Annual Report. Vancouver: Fraser Institute, 2013. Available at www.freetheworld.com.

Hanson J. and Sigman R. (2013) "Leviathan's Latent Dimensions: Measuring State Capacity for Comparative Political Research." Paper presented at the World Bank Political Economy Brown Bag Lunch Series, March 21, 2013.

Hendrix, C. S. (2010). Measuring state capacity: Theoretical and empirical implications for the study of civil conflict. Journal of Peace Research, 47(3):273-285.

Holmberg S., Rothstein B. and Nasiritousi N. (2009) "Quality of Government: What You get", Annual Review of Political Science, 12:135-61.

Hulme, David (2010) Global Poverty: How Global Governance is Failing the Poor. London, Routledge.

Hulme D., Antonio Savoia and Kunal Sen (2014). "Governance as a global development goal? Setting, measuring and monitoring the Post-2015 Development Agenda". ESID Working Paper No. 32. Manchester, UK: University of Manchester. Available at: http://www.effective-states.org/working-paper-32/.

ICRG (2012). "International Country Risk Guide Researchers Dataset, Table 3B". The Political Risk Services Group, third edition. 
Kauffman D. and A. Kraay (2008) "Governance Indicators: Where Are We, Where Should We be Going?”, World Bank Research Observer, 23(1): 1-30.

Kurtz M.J. and Schrank A. (2007) "Growth and Governance: Models, Measures, and Mechanisms.” Journal of Politics Vol. 69:2 (May).

Lin Y.L. and Nugent J. (1995) "Institutions and Economic Development”, in Behrman J. and Srinivasan T.N. (eds.), Handbook of Development Economics, vol.III, Elsevier Science.

Lange, Matthew and Dietrich Rueschemeyer (eds.). 2005. States and Development: Historical Antecedents of Stagnation and Advance. Palgrave Macmillan Press.

Lawson-Remer T., (2012), Property Insecurity, Brooklyn Journal of International Law, 38(1): 145-188.

Mazzuca S. L. (2010) “Access to Power Versus Exercise of Power Reconceptualizing the Quality of Democracy in Latin America", Studies in Comparative International Development, 45:334-357

Mulligan Casey B., Ricard Gil and Xavier Sala-i-Martin, 2004. "Do Democracies Have Different Public Policies than Nondemocracies?," Journal of Economic Perspectives, vol. 18(1), pages 51-74, Winter.

Nelson, P. (2007), Human Rights, the Millennium Development Goals, and the Future of Development Cooperation, World Development, Vol. 35, No. 12, pp. 2014-2055.

Ottervik, M. (2013), "Conceptualizing and Measuring State Capacity: Testing the Validity of Tax Compliance as a Measure of State Capacity", Quality of Government Institute Working Paper no. 20.

Pritchett, L., M. Woolcock and M. Andrews (2013), "Looking Like a State: Techniques for Persistent Failure in State Capability for Implementation", Journal of Development Studies, Vol. 49, No. 1, pp. 1-18.

Rajkumar A.S. and Swaroop V. (2008) "Public Spending and Outcomes: Does Governance Matter?”, Journal of Development Economics, 86 (2008) 96-111

Rauch J.E and Evans P. (2000) "Bureaucratic Structure and Bureaucratic Performance in Less Developed countries", Journal of Public Economics, 75: 49-71.

Rodrik, Dani, Subramanian, Arvind and Francesco Trebbi (2004). Institutions rule: the primacy of institutions over geography and integration in economic development. Journal of Economic Growth, 91:131-165.

Savoia, A. and K. Sen (2013), "Do We See Convergence in Institutions: A Cross-Country Analysis", Development Economics and Public Policy Working Paper Series No.33, University of Manchester.

Savoia A. and Sen K. (2014) "Measurement, Evolution, Determinants and Consequences of State Capacity: a Review of Recent Research", Journal of Economic Surveys, forthcoming.

Sundaram, Jomo Kwame and Chowdhury, Anis (2012) Is Good Governance Good for Development? London: Bloomsbury Academic. 
Tabellini G. (2005) "The Role of the State in Economic Development", Kyklos, 58(2): 283303.

Teorell, Jan, Nicholas Charron, Stefan Dahlberg, Sören Holmberg, Bo Rothstein, Petrus Sundin \& Richard Svensson. 2013. The Quality of Government Dataset, version 15May13. University of Gothenburg: The Quality of Government Institute, http://www.qog.pol.gu.se.

UNDP (2011), Towards Democratic Accountability, mimeo.

United Nations (2013), Report of the High-Level Panel on Post-2015 MDGs. New York, UN.

Van de Walle, S. (2009). 'International comparisons of public sector performance: how to move ahead?' Public Management Review. 11(1): 39-56.

Ward, Michael (2004) Quantifying the World: UN Ideas and Statistics. Bloomington, Indiana University Press.

Williams A. and Siddiqui A. (2008) "The Use (and Abuse) of Governance Indicators in Economics: a Review", Economics of Governance, 9(2): 131-175.

World Bank (1992) Governance and Development. Washington D.C.: World Bank.

World Bank (2011) Worldwide Governance Indicators (WGI) project. Data available at: http://info.worldbank.org/governance/wgi/index.asp.

World Bank (2002). "Country policy and institutional assessment 2002 assessment questionnaire", http://siteresources.worldbank.org/IDA/Resources/CPIA2002.pdf.

\section{Figures and Tables}

\begin{tabular}{|l|}
\hline Table 1: The UN High Level Panel's Illustrative Goal for Governance \\
\hline Goal 10: Ensure Good Governance and Effective Institutions \\
a) Provide free and universal legal identity, such as birth registrations \\
b) Ensure that people enjoy freedom of speech, association, peaceful protest and access to independent media \\
and information \\
c) Increase public participation in political processes and civic engagement at all levels \\
d) Guarantee the public's right to information and access to government data \\
e) Reduce bribery and corruption and ensure officials can be held accountable \\
\hline Source: UN High Level Panel, United Nations (2013: 50) \\
\hline
\end{tabular}

\begin{tabular}{|l|l|l|l|}
\hline Table 2: classification and properties of governance measures \\
\hline Type of measure & \multicolumn{1}{|c|}{ Objective } & \multicolumn{1}{|c|}{ Subjective } \\
\hline based on: & Proxies from hard data & De jure rules & De facto rules \\
\hline Advantages & Not affected by observer's bias. & $\begin{array}{l}\text { (i) Not affected by observer's } \\
\text { bias; } \\
\text { (ii) can isolate specific } \\
\text { governance dimensions. }\end{array}$ & $\begin{array}{l}\text { Capture formal and informal } \\
\text { rules. }\end{array}$ \\
\hline Limitations & $\begin{array}{l}\text { May not capture the functioning } \\
\text { governance; } \\
\text { (ii) do not address specific } \\
\text { governance aspects. }\end{array}$ & $\begin{array}{l}\text { (i) Affected by observer's bias; } \\
\text { (ii) unable to isolate specific } \\
\text { governance dimensions. }\end{array}$ \\
\hline
\end{tabular}




\begin{tabular}{|c|c|c|c|}
\hline Index and source & Methodology & Coverage & Data \\
\hline \multicolumn{4}{|c|}{ Bureaucratic and administrative quality } \\
\hline $\begin{array}{l}\text { Bureaucratic quality, ICRG } \\
(2012)\end{array}$ & $\begin{array}{l}\text { Subjective. Experts' assessments which indicate autonomy from } \\
\text { political pressure and strength and expertise to govern without drastic } \\
\text { changes in policy or interruptions in government services and also the } \\
\text { existence of an established mechanism for recruiting and training. }\end{array}$ & $\begin{array}{l}145 \\
\text { countries }\end{array}$ & $\begin{array}{l}\text { Panel, } \\
1984- \\
2011\end{array}$ \\
\hline $\begin{array}{l}\text { Government effectiveness, } \\
\text { WGIs (World Bank 2011) }\end{array}$ & $\begin{array}{l}\text { Subjective. Expert assessments and surveys. It captures perceptions of } \\
\text { the quality of public services, the quality of the civil service and the } \\
\text { degree of its independence from political pressures, the quality of } \\
\text { policy formulation and implementation, and the credibility of the } \\
\text { government's commitment to such policies. Aggregating components } \\
\text { from various sources. Continuous, original scale: }-2.5 \text { to } 2.5 \text {. }\end{array}$ & $\begin{array}{l}202 \\
\text { countries }\end{array}$ & $\begin{array}{l}\text { Panel, } \\
1996- \\
2011\end{array}$ \\
\hline $\begin{array}{l}\text { Bureaucratic compensation, } \\
\text { career opportunities and } \\
\text { meritocratic recruitment - } \\
\text { Evans and Rauch's (1999, } \\
2000 \text { ) }\end{array}$ & $\begin{array}{l}\text { Subjective. Experts' survey (academics and non) answering } \\
\text { questionnaires on "Career Opportunities", "Bureaucratic compensation } \\
\text { and "Meritocratic recruitment". The three measures are equal-weight } \\
\text { indices of a subset of questions eliciting evaluations on recent history } \\
\text { (roughly 1970-1990 period), ranging all from } 0 \text { to } 1 \text {. }\end{array}$ & $\begin{array}{l}35 \text { less } \\
\text { developed } \\
\text { economies }\end{array}$ & $\begin{array}{l}\text { Cross- } \\
\text { section, } \\
1970- \\
1990\end{array}$ \\
\hline $\begin{array}{l}\text { Quality of public } \\
\text { administration - Country } \\
\text { Policy and Institutional } \\
\text { Assessments (World Bank } \\
\text { 2002) }\end{array}$ & $\begin{array}{l}\text { Subjective. Expert assessment of the extent to which civilian central } \\
\text { government staffs (including teachers, health workers, and police) are } \\
\text { structured to design and implement government policy and deliver } \\
\text { services effectively. }\end{array}$ & $\begin{array}{l}77 \text { less } \\
\text { developed } \\
\text { economies }\end{array}$ & $\begin{array}{l}\text { Panel, } \\
2005- \\
2011\end{array}$ \\
\hline \multicolumn{4}{|l|}{ Legal capacity } \\
\hline $\begin{array}{l}\text { Steering capability, BTI, } \\
\text { Bertelsmann Foundation } \\
\text { (2011) }\end{array}$ & $\begin{array}{l}\text { Subjective. Expert assessment evaluating to what extent the political } \\
\text { leadership sets and maintains strategic priorities; how effective the } \\
\text { government is in implementing reform policy; how flexible and } \\
\text { innovative the political leadership is; and if the political leadership } \\
\text { learns from past errors. }\end{array}$ & $\begin{array}{l}119 \text { less } \\
\text { developed } \\
\text { economies }\end{array}$ & $\begin{array}{l}\text { Cross- } \\
\text { section, } \\
2006\end{array}$ \\
\hline $\begin{array}{l}\text { Quality of Legal System and } \\
\text { Property rights, Fraser } \\
\text { Institute }\end{array}$ & $\begin{array}{l}\text { Subjective assessment combining survey and exerts' opinions, ranging } \\
\text { between } 1 \text { and } 10 \text {; a higher score corresponds to a stronger protection } \\
\text { of private property rights. }\end{array}$ & $\begin{array}{l}139 \\
\text { countries }\end{array}$ & $\begin{array}{l}\text { Panel, } \\
1970- \\
2008\end{array}$ \\
\hline $\begin{array}{l}\text { Rule of law, WGI (World } \\
\text { Bank 2011) }\end{array}$ & $\begin{array}{l}\text { Subjective. Expert assessments and surveys. Aggregating components } \\
\text { from various sources. Continuous, original scale: }-2.5 \text { to } 2.5 \text {. It captures } \\
\text { perceptions of the extent to which agents have confidence in and abide } \\
\text { by the rules of society, and in particular the quality of contract } \\
\text { enforcement, property rights, the police, and the courts, as well as the } \\
\text { likelihood of crime and violence. }\end{array}$ & $\begin{array}{l}202 \\
\text { countries }\end{array}$ & $\begin{array}{l}\text { Panel, } \\
1996- \\
2010\end{array}$ \\
\hline Rule of law, ICRG (2012) & $\begin{array}{l}\text { Subjective. It reflects the degree to which the citizens of a country are } \\
\text { willing to accept the established institutions to make and implement } \\
\text { laws and adjudicate disputes, its scores evaluate soundness of political } \\
\text { institutions, the strength of the court system, and the provisions for an } \\
\text { orderly succession of power, as opposed to a tradition depending on } \\
\text { physical force or illegal means to settle claims. }\end{array}$ & $\begin{array}{l}145 \\
\text { countries }\end{array}$ & $\begin{array}{l}\text { Panel, } \\
1984- \\
2011\end{array}$ \\
\hline \multicolumn{4}{|l|}{$\begin{array}{l}\text { Transparency and } \\
\text { Accountability }\end{array}$} \\
\hline $\begin{array}{l}\text { Right to Information, and } \\
\text { Freedom of the Media, Global } \\
\text { Integrity (2011) }\end{array}$ & $\begin{array}{l}\text { Both Objective and Subjective. Expert assessment and surveys of } \\
\text { whether laws exists on the books on whether citizens have the legal } \\
\text { right to information, and whether the freedom of the media is } \\
\text { guaranteed, and whether in practice, this is the case. From a scale of } 0 \\
\text { to } 100 \text {. }\end{array}$ & 31 countries & $\begin{array}{l}\text { Panel, } \\
2006- \\
2011\end{array}$ \\
\hline $\begin{array}{l}\text { Open Budget Survey, } \\
\text { International Budget } \\
\text { Partnership (2012) }\end{array}$ & $\begin{array}{l}\text { Subjective, Expert assessment of the degree to which country budgets } \\
\text { are transparent, and the extent of civil society and citizen budget } \\
\text { monitoring }\end{array}$ & $\begin{array}{l}100 \\
\text { countries }\end{array}$ & $\begin{array}{l}\text { Panel, } \\
2008 \\
2010 \\
2012\end{array}$ \\
\hline
\end{tabular}

Table 4: Governance quality the world around: 2000-2010

\begin{tabular}{|l|l|l|l|l|}
\hline \multicolumn{2}{|l|}{ Panel (a): Quality of legal structure and security of property rights index } \\
\hline Year & $\mathbf{2 0 0 0}$ & $\mathbf{2 0 0 5}$ & $\mathbf{2 0 1 0}$ \\
\hline Whole sample & Mean & 5.83 & 5.85 & 5.60 \\
& CV & 0.33 & 0.30 & 0.29 \\
& N & 123 & 139 & 142 \\
\hline Advanced Economies & Mean & 8.34 & 8.17 & 7.64
\end{tabular}




\begin{tabular}{|c|c|c|c|c|}
\hline & $\begin{array}{l}\mathrm{CV} \\
\mathrm{N}\end{array}$ & $\begin{array}{l}0.14 \\
30\end{array}$ & $\begin{array}{l}0.11 \\
30\end{array}$ & $\begin{array}{l}0.12 \\
30\end{array}$ \\
\hline Developing Economies & $\begin{array}{l}\text { Mean } \\
\text { CV } \\
\mathrm{N}\end{array}$ & $\begin{array}{l}4.87 \\
0.27 \\
78\end{array}$ & $\begin{array}{l}5.05 \\
0.28 \\
86\end{array}$ & $\begin{array}{l}4.84 \\
0.27 \\
87\end{array}$ \\
\hline Transition Economies & $\begin{array}{l}\text { Mean } \\
\text { CV } \\
\mathrm{N}\end{array}$ & $\begin{array}{l}5.82 \\
0.14 \\
15\end{array}$ & $\begin{array}{l}5.73 \\
0.17 \\
23\end{array}$ & $\begin{array}{l}5.69 \\
0.12 \\
25\end{array}$ \\
\hline \multicolumn{5}{|c|}{ Panel (b): Quality of Government index } \\
\hline Whole sample & $\begin{array}{l}\text { Mean } \\
\text { CV } \\
\mathrm{N}\end{array}$ & $\begin{array}{l}5.65 \\
0.36 \\
140\end{array}$ & $\begin{array}{l}5.28 \\
0.39 \\
140\end{array}$ & $\begin{array}{l}5.37 \\
0.38 \\
139\end{array}$ \\
\hline Advanced Economies & $\begin{array}{l}\text { Mean } \\
\text { CV } \\
\mathrm{N}\end{array}$ & $\begin{array}{l}8.55 \\
0.14 \\
30\end{array}$ & $\begin{array}{l}8.42 \\
0.14 \\
30\end{array}$ & $\begin{array}{l}8.44 \\
0.13 \\
30\end{array}$ \\
\hline Developing Economies & $\begin{array}{l}\text { Mean } \\
\text { CV } \\
\mathrm{N}\end{array}$ & $\begin{array}{l}4.67 \\
0.29 \\
87 \\
\end{array}$ & $\begin{array}{l}4.24 \\
0.30 \\
87\end{array}$ & $\begin{array}{l}4.37 \\
0.28 \\
87 \\
\end{array}$ \\
\hline Transition Economies & $\begin{array}{l}\text { Mean } \\
\text { CV } \\
\text { N }\end{array}$ & $\begin{array}{l}5.45 \\
0.29 \\
23\end{array}$ & $\begin{array}{l}5.05 \\
0.22 \\
23\end{array}$ & $\begin{array}{l}5.06 \\
0.23 \\
22\end{array}$ \\
\hline \multicolumn{5}{|c|}{$\begin{array}{l}\text { Notes: data is from Qwartney et al (2013) and Teorell et al (2013). Higher values indicate greater governance quality. The } \\
\text { statics reported are the simple average (Mean), the coefficient of variation (CV) and the sample size (N). The trends are } \\
\text { very similar also when the same statistics are calculated keeping the sample size equal to the one in the initial year and } \\
\text { constant over time. Countries' classification follows the IMF system: based on per capita income level, export } \\
\text { diversification and degree of integration into the global financial system } \\
\text { (http://www.imf.org/external/pubs/ft/weo/2011/01/weodata/groups.htm, accessed on } 25 / 6 / 2013) \text {. }\end{array}$} \\
\hline
\end{tabular}
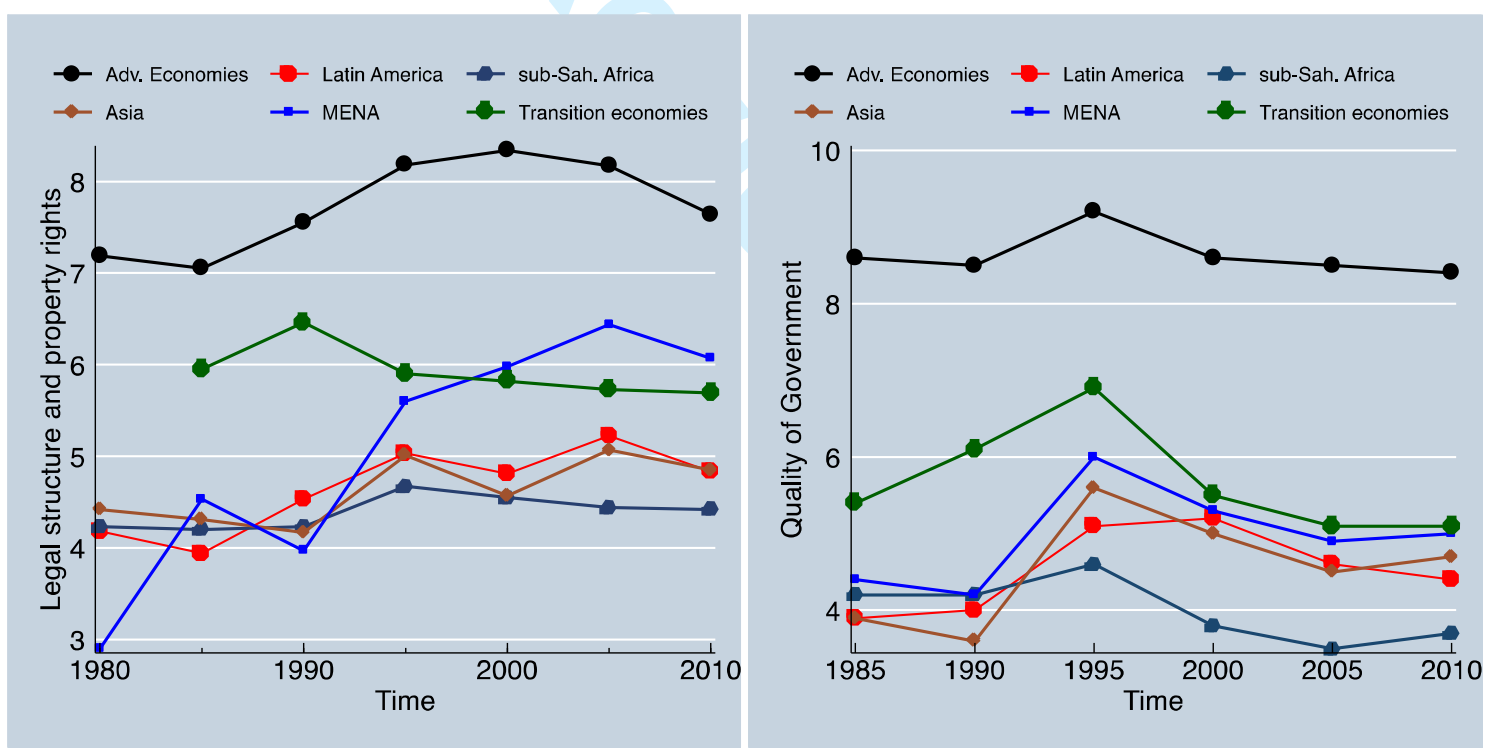

Figure 1 - Governance quality time paths by level of development

${ }^{\mathrm{i}}$ A similar argument can be made for not including the achievement of human rights as a core component of good governance. While successful institutionalisation and legalisation of human rights are important as ends in themselves in the development process, these can be seen as neither necessary nor sufficient in the delivery of development goods (Nelson 2007)

${ }^{i i}$ In economics, thorough surveys on measuring governance are Williams and Siddiqui (2008) and Kauffman and Kraay (2008). Within the public administration scholarship, an effective review of the debate on public sector performance is Van de Walle (2009). 
ii Political scientists have produced powerful critiques, lamenting the lack of conceptual clarity and the uncertainty of ratings (Kurtz and Schrank 2007; Hanson and Sigman 2013).

iii Recent work by political scientists, such as Hanson and Sigman (2013), use factor analytic methods such as Bayesian latent variable analysis to construct composite measures of governance and state capacity from different dimensions of governance. However, as Goertz (2006) notes, the relationship between the indicators of governance used in the factor analytic methods and the concept of governance as broadly understood is often tenuous.

${ }^{\text {iv }}$ See Hulme et al (2014) for more statistical evidence.

v The apparent improvement in governance quality measures in this period needs further investigation and is the subject of a separate paper - see Savoia and Sen (2013). At least in part, this could be because western countries stopped allocating foreign aid to 'bad' regimes (for example, Banda in Malawi and Mobutu in the Congo were aid recipients during the Cold War to ensure they did not support the Soviet Union even though donors knew that they were badly governing their respective states).

${ }^{v i}$ An additional factor limiting both policy and academic research is the short time coverage of existing databases. Unfortunately, no measures have substantial time-series variation. But governance phenomena are persistent and trends should be studied over the long run (see Savoia and Sen 2014). There is a lot to gain from bringing temporal depth to governance measures in the future. Monitoring and policy design could be better informed by understanding the historical evolution of governance phenomena. Academic research could offer better support to policy makers, if it will be able to draw on time-series variation when the tracing the effects and origins of good governance.

vii See Chang (2011) and Lawson-Remer (2012) for a critical perspective on institutions and growth.

viii The issue of exactly 'what' data national statistical agencies should collect, the methods to be used and 'how' international standards could be agreed merits detailed thought but we are not able to cover it in this paper. The recent Strategy for the Harmonisation of Statistics in Africa (SHaSA) Report covers such issues for non-governance measures (African Union nd).

${ }^{\text {ix }}$ In addition to setting targets the MDGs also informally utilised a comparative performance approach to target achievement. By listing countries that were 'on' and 'off' track for target achievement a 'league table' element was brought into play. 